\title{
KRISTEN DAN KENAIFAN POLITIK: KRITIK ATAS SIKAP POLITIK PGPI DALAM PILPRES 2014
}

\author{
Victor Silaen \\ Dosen Universitas Pelita Harapan
}

\begin{abstract}
Politics is an aspect and a system that is very important in the lives of citizens. All citizens including Christians cannot shy away from politics, because of politics produce various public policies. Thus Christians are supposed to take part in political life, not only in the electoral arena, but also in other areas. In the event the election, churches should not be naïve. Churches must wisely give political enlightenment to their congregations, instead of the other way, lead the congregation to elect candidates of certain leaders.

Thus the "political letter" issued by PGPI during the 2014 Presidential Election should be criticized as naïve, since the content dictated the churches under PGPI. In addition, issues brought up in the letter were entirely unfounded. It is no surprise that PGPI Chairman, Rev. Dr. Jacob Nahuway, MA, received much criticism and scorn.
\end{abstract}

KEYWORDS: politics, political participation, power, nation, country, religion.

ABSTRAK: Politik adalah aspek dan sistem yang sangat penting di dalam kehidupan kita sebagai warga negara. Kita, 
termasuk Kristen, tak mungkin menghindar dari politik, karena politiklah yang membuat pelbagai kebijakan bagi publik. Maka, Kristen pun seharusnya turut mengambil bagian dalam kehidupan berpolitik. Bukan hanya di ajang pemilu, tapi juga dalam konteks-konteks lainnya. Di ajang pemilu, gereja-gereja tak boleh naif. Gereja-gereja harus secara bijaksana memberikan pencerahan politik kepada warga jemaatnya. Bukan sebaliknya, menggiring jemaat untuk memilih calon pemimpin tertentu.

Terkait itulah maka "surat politik" yang dikeluarkan oleh PGPI menjelang Pilpres 2014 yang lalu patut dikiritisi sebagai sesuatu yang naif. Sebab isinya bukan hanya mendikte gerejagereja dalam naungan PGPI, tetapi juga tidak berdasar sama sekali. Tak heran, dikarenakan hal itu Ketua Umum PGPI, Pendeta Dr Jacob Nahuway, MA, banyak mendapat kritik, bahkan cemooh.

KATA KUNCI: politik, partisipasi politik, kekuasaan, negara, agama.

Tulisan ini membahas tentang Kristen dan politik, khususnya di Indonesia. Terlebih dulu diuraikan tentang apa itu politik dan partai politik, lalu Kristen dan politik, yang kemudian dilanjutkan dengan fenomena perpolitikan di Indonesia, khususnya di seputar penyelenggaraan pemilu presiden dan wakil presiden (pilpres) tahun 2014 yang lalu.

Indonesia adalah negara hukum dan bukan negara yang berdasarkan agama. Atas dasar itu itu politik seharusnya mengedepankan hal-hal yang bersifat nasionalis, bukan agamis. 
Sebab, politik itu sendiri merupakan wahana untuk memperjuangkan kepentingan orang banyak dan bukan untuk segelintir orang atau kelompok-kelompok tertentu saja.

\section{KRISTEN DAN POLITIK}

Wacana tentang "Kristen dan Politik di Indonesia" merupakan topik yang tetap menarik meski sebenarnya agak usang, karena sudah banyak buku maupun artikel ilmiah dan semi-ilmiah yang membahas soal ini. Namun demikian, menjelang pemilihan umum (pemilu) diselenggarakan, selalu saja topik ini mampu memunculkan daya tarik tersendiri. Maka, jangan heran kalau sebagian gereja merasa "terpanggil" untuk mewacanakannya kembali melalui forum-forum seminar atau diskusi. Ada baiknya juga, karena faktanya selalu saja ada warga gereja yang bingung bersikap ketika harus menyambut pemilu dengan partisipasi konkret.

Pertanyaannya, mengapa mereka bingung? Jawabannya sederhana: karena oleh sebagian Kristen, politik masih dianggap kotor, sehingga karena itu ditabukan. Memang, dalam kenyataannya, praktik politik kerap dipenuhi perilaku pragmatis dan oportunistik, yang membuat politik distigmakan sebagai ranah kehidupan yang sarat intrik dan taktik licik. Sedemikian buruknya politik, sehingga di ranah tersebut tak dikenal pertemanan dan permusuhan yang abadi, karena yang abadi adalah kepentingan (baik pribadi maupun golongan) 
yang harus diperjuangkan habis-habisan. ${ }^{1}$ Kepentingan itu sendiri beraneka-ragam, namun yang pasti pencapaiannya haruslah ditunjang oleh kekuasaan. Maka, dalam konteks politik internasional, nasional maupun lokal, perjuangan yang terutama adalah mengejar kekuasaan, demikian dikatakan oleh ilmuwan politik Hans Joachim Morgenthau (2005).

Itulah esensi politik: kekuasaan (power). Dengan kekuasaan di tangan, pelbagai kepentingan menjadi mudah untuk dicapai. Dikarenakan hal itulah maka kekuasaan memiliki dua wajah: memesona dan mengerikan (tremendum et fascinatum). ${ }^{2}$ Karena daya pikatnyalah maka pada umumnya manusia selalu mencari, mengejar, mempertahankan dan sedapat mungkin memperbesarnya (zoon politicon). Tapi juga karena daya rusaknyalah maka manusia dapat menjadi serigala bagi sesamanya (homo homini lupus).

Dikarenakan banyaknya orang yang memandang politik hanya dari sisi-sisi kelamnya itu, maka politik pun akhirnya menjadi sesuatu yang dijauhkan, bahkan ditabukan. Disebabkan hal itulah maka selanjutnya banyak orang yang tak

${ }^{1}$ Itulah adagium terkenal filsuf politik dan negarawan Inggris abad ke-19, Lord Palmerston. Dalam bahasa aslinya berbunyi begini: “We have no eternal allies, and we have no perpetual enemies. Our interests are eternal and perpetual, and those interests it is our duty to follow." Matthew Hanzel, "International Relations Quotes," Matthew Hanzel's Blog: International Relations, Politics, Technology, Books, Music, diakses Desember 18, 2012, http://matthewhanzel.com/international-relations-quotes.

2 Istilah yang dikutip dari Rudolf Otto, dalam Eddy Kristiyanto, OFM, Sakramen Politik - Mempertanggung-jawabkan Memoria (Yogyakarta: Penerbit Lamalera, 2008), 6. 
sedikit pun berhasrat untuk belajar politik. Jangankan belajar, untuk sekadar tahu saja pun tak mau. Kalaupun mereka terpaksa bersentuhan dengan politik, itu hanya sebatas memberikan suara di ajang pemilu. Selepas itu, politik pun kembali terpinggirkan bahkan terabaikan. Padahal politik merupakan aspek dan sistem kehidupan yang sangat penting. Politiklah yang membuat pelbagai kebijakan bagi publik. Atas dasar itu maka setiap warga negara seharusnya mengambil bagian dalam kehidupan politik.

Tulisan ini selanjutnya membahas tentang hakikat politik, Kristen, partisipasi politik Kristen, dan Pemilu 2014, serta halhal penting di seputar isu-isu tersebut.

\section{POLITIK DAN PARTAI POLITIK}

Dalam literatur ilmu politik terdapat banyak sekali definisi tentang politik. Namun intinya, politik itu berkait erat dengan pembuatan kebijakan (policy making) yang menyangkut kehidupan orang banyak (public). Karena itulah politik selalu berhubungan dengan pemerintahan (polity), yang dahulu kala berada di wilayah kota (bahasa Yunani: polis). Jadi, merujuk politikos dan politheia (dalam bahasa Yunani), politik itu mencakup negara dan warga negara. ${ }^{3}$

Politik, karena itu, selalu berurusan dengan kekuasaan (kemampuan mempengaruhi pihak lain agar mengikuti apa yang kita kehendaki) dan kepentingan. Untuk itu politik juga

${ }_{3}^{3}$ J.H. Rapar, Filsafat Politik Aristoteles (Jakarta: Rajawali Press, 1993), 30. 
melibatkan sistem, proses, dan aktor-aktornya. Maka, jika disederhanakan, politik dapat didefinisikan sebagai "who gets what, when, and how".4 Di situ terkandung pelbagai kemungkinan tentang "siapa mendapat apa, kapan dan bagaimana". Karena itulah maka politik juga bisa diartikan sebagai "the art of possibilities" (seni mengelola pelbagai kemungkinan). "Semua mungkin diwujudkan" atau "semua mungkin dicapai", kira-kira begitulah artinya jika diterjemahkan ke dalam bahasa sehari-hari. Jadi dalam politik, apapun itu, yang penting adalah seninya (atau strateginya). Apakah politik yang dilakukan oleh seseorang atau sekelompok orang itu terlihat "cantik" bagi publik? Begitulah kira-kira. Maka, siapa pun bisa masuk ke dunia politik - tinggal soal seninya atau strateginya "bagus" atau "tidak bagus", itu saja.

Sama seperti aspek-aspek kehidupan lainnya, politik sesungguhnya baik karena ia berorientasi pada tercapainya kebaikan bersama (common good). Alain Badiou (2002) menegaskan bahwa politik merupakan ruang di mana tujuantujuan untuk kebaikan bersama dipertaruhkan. ${ }^{5}$ Atas dasar itu Badiou menjungkirbalikkan anggapan teleologis bahwa politik

${ }^{4}$ Harold D. Lasswell dan Abraham Kaplan, Power and Society: A Framework for Political Inquiry (New Jersey: Transaction Publishers, 2014), 74.

${ }^{5}$ Dikutip dari Daniel Hutagalung, "Politik Untuk Kebaikan Bersama." Tempo.co Kolom Oktober 6, 2008. http://www.tempo.co/read/kolom/2008/10/06/31/Politik-Untuk-KebaikanBersama. 
adalah wilayah kotor, haram dan licik. Menurut Badiou, pada politik kita menyandarkan harapan-harapan untuk membangun sesuatu yang baik bagi semua orang. Politik adalah baik, karena itu subjek politik haruslah individu atau sekelompok individu yang memiliki tujuan-tujuan bagi kebaikan bersama.

Senada dengan Badiou, Norberto Bobbio (2003) menekankan bahwa tujuan dari politik adalah menciptakan public good atau kebaikan bagi publik. Kekuasaan politik diperebutkan untuk menciptakan sesuatu yang baik bagi semua, dan partai politik (parpol) merupakan alat untuk mencapai tujuan-tujuan tersebut. ${ }^{6} \mathrm{Di}$ sisi lain, menurut Bobbio, tubuh kepolitikan kontemporer juga menghadapi sejumlah persoalan pokok. Bobbio mengidentifikasi dua soal pokok, yakni: personal party dan money politics.

Kritik Bobbio berangkat dari muncul dan berkembangnya sebuah partai di Italia yang menamakan diri Forza Italia. Partai ini dipimpin oleh konglomerat media Silvio Berlusconi. Forza Italia adalah partai yang baru didirikan pada 1993, namun secara mengejutkan memenangkan pemilu Italia tahun 1994, dan membawa Berlusconi menduduki jabatan perdana menteri. Bagi Bobbio, personal party merupakan sebuah partai yang diciptakan oleh dan untuk satu orang. Ini berbeda dengan

${ }^{6} \mathrm{Ibid}$. Adanya parpol di suatu negara menunjukkan setidaknya negara itu sudah demokratis. Tapi tentu saja jika jumlah parpol lebih dari satu. Sebab kalau hanya satu berarti tidak ada pilihan, dan itu berarti antidemokrasi. Parpol-parpol itu secara periodik berkompetisi untuk meraih kekuasaan sebesar-besarnya, melalui sebuah ajang yang disebut pemilu. 
partai sebagaimana yang dipahami secara umum, yakni sebuah asosiasi dari sekumpulan orang. Partai Forza Italia merupakan personal party, karena bukan perhimpunan yang menciptakan pemimpin, melainkan pemimpin yang menciptakan perhimpunan.

Dalam partai seperti ini umumnya hanya ada loyalitas buta anggota partai terhadap pemimpin atau tokohnya; bukan pada ide-ide, proyek politik, rencana, bahkan ide-ide utopis dari partai tersebut. Atas dasar itu personal party bukanlah partai yang dibangun untuk tujuan-tujuan public good, melainkan untuk tujuan-tujuan personal atau pribadi. Model partai seperti ini, menurut Bobbio, tak akan bertahan lama, karena begitu si tokoh tak lagi berada di partai, maka partai tersebut perlahan-lahan akan pecah, mengecil, dan kemungkinan besar mati.

Sedangkan Giovanni Sartori (1976) menyebut ada dua model parpol. ${ }^{7}$ Pertama, yang berorientasi negara (state centered). Kedua, yang berorientasi masyarakat (society centered). Model pertama mengharuskan negara memiliki program ekonomi politiknya sendiri, yang untuk mencapainya, pemerintah harus berada pada posisi yang mengontrol setiap situasi dan kondisi selama jangka waktu yang relatif panjang. Jadi, meski sistem politik modern memberi peluang adanya parpol-parpol yang saling berkompetisi, namun arah politik harus tetap berjalan di dalam kontrol pemerintah.

${ }^{7}$ Giovanni Sartori, Parties and Party System: A Framework for Analysis, Vol.1 (New York: Cambridge University Press, 1976), 31-35. 
Caranya, bisa dengan menjadikan parpol tertentu sebagai primadona yang selalu mendapatkan dukungan dan fasilitas untuk memenangkan pemilu. Karena, jika sang primadona menang, setidaknya ada jaminan bagi kesinambungan program yang sudah dicanangkan itu.

Sementara itu model kedua justru membiarkan negara untuk tidak memiliki program ekonomi politiknya sendiri. Sebaliknya, setiap parpol diharuskan saling berkompetisi menjajakan masing-masing. Pertanyaannya, program siapa yang akan dilaksanakan untuk dan atas nama negara? Jawabannya: untuk itulah pemilu diselenggarakan, untuk menentukan siapa lebih layak mengontrol negara berdasarkan programnya. Maka, dalam konteks ini, masing-masing parpol diposisikan setara dan tidak ada yang diistimewakan oleh negara. Sebab, parpol yang menang akan sangat mungkin berganti-ganti, setiap kali pemilu diselenggarakan. Jadi, negara memang terus-menerus dikondisikan untuk menghormati setiap parpol yang ada. Niscaya demikian pulalah rakyat selaku pemberi suara kepada parpol-parpol itu, juga bersikap serupa.

Kembali pada Bobbio, ada bahaya lain yang harus diperhatikan: politik uang (money politics). Tak dapat disangkal bahwa politik uang merupakan salah satu ancaman serius bagi demokrasi. Personal party bisa hidup dan berkembang, salah satunya, dengan politik uang. Pemimpin yang memiliki dan mengandalkan uanglah yang mampu membangun personal party. Menurut Bobbio, suara rakyat bisa dibeli seperti layaknya barang. Ini merupakan alasan mendasar kenapa uang bisa 
merusak republik. Siapa yang memiliki uang lebih banyak, bisa membeli suara lebih banyak. Bobbio mencontohkan Amerika Serikat (AS), di mana yang pertama-tama dilakukan para kandidat presiden untuk ikut pemilu adalah mencari dukungan dana (funding).

\section{POLITIK KRISTEN}

Lalu bagaimana dengan politik Kristen? Jikalau Kristen didefinisikan sebagai pengikut Kristus, maka tentunya orangorang Kristen adalah mereka yang sehati dan sepikir dengan Kristus. Pertanyaannya, bagaimana Kristus memandang politik? Apakah Kristus, semasa hidup-Nya di dunia ini, berhubungan dengan politik?

Sejarah mencatat bahwa Kristus, yang bernama Yesus, lahir dan beranjak dewasa dalam sebuah struktur masyarakat dengan kelas-kelas sosial bervariasi. Saduki adalah kelas sosial atas yang memiliki harta kekayaan melimpah dan minoritas. Meski demikian, kelas ini tidak tergolong kelas aristokratik, karena adat mereka yang kasar.

Di bawah itu ada Farisi, yang termasuk kelas menengah, bersahabat, berwatak urban dan sebagian memiliki watak revolusioner. Selanjutnya kelas ketiga, Am Haaretz, adalah kelas terbawah yang terdiri dari kaum tani, buruh kasar, lumpen proletariat. Beberapa sejarawan menyebut mereka sebagai kelas Esseni. ${ }^{8}$ Inilah kelas yang paling tertindas di zaman Sebelum

${ }^{8}$ Lihat Erich Fromm, The Dogma of Christ and Other Essays on Religion, Psychology and Culture (New York, Chicago, San Francisco: Holt, Rineharta 
Masehi (SM), baik oleh kelas-kelas lain di masyarakat maupun oleh Imperium Romawi. Kepada merekalah kelak Yesus lebih menunjukkan keberpihakan-Nya, dan sebaliknya, dibanding kelas-kelas lainnya, merekalah yang lebih mendukung Yesus dalam melaksanakan misi-Nya saat itu.

Sebelum Yesus lahir, gerakan pemberontakan bangsa Yahudi kerap muncul akibat kekejaman dan kejahatan politik Imperium Romawi selama berabad-abad. Puncaknya adalah ketika kaum Farisi mendukung aliansi kekuatan antara kelas bawah perkotaan dan kelas bawah pedesaan, yang melahirkan kelompok Zelot. Tak tahan menderita akibat penindasan, kaum Zelot kemudian mencetuskan pemberontakan massa. Hal itu dipicu oleh pemaksaan Imperium Romawi untuk meletakkan patung kaisar di Bait Yerusalem (Temple of Jerusalem). ${ }^{9}$ Namun demikian, kaum pemberontak itu berhasil ditumpas oleh Imperium Romawi. Akibatnya meningkatlah radikalisasi di kalangan kaum pemberontak itu, dan itulah yang seiring waktu dan secara psikologis menyebabkan terjadinya transformasi gerakan ke arah mesianistik. Rakyat merindukan lahirnya seorang juruselamat (mesias).

Suatu saat muncullah seorang yang bernama Yohanes Pembaptis, yang dianggap sebagai pelopor gerakan spiritual. Karakteristiknya lemah-lembut dan menekankan kasih, serta

and Winston, 1963), 3-91.

${ }^{9}$ Ini terjadi di masa Kaisar Kaligula memerintah Romawi (37-41 SM). Bukan sekadar peletakan patung itu yang memicu pemberontakan, tapi juga pemaksaan Imperium Romawi agar bangsa Yahudi mempertuhankan Kaisar. ibid, 28-29. 
menghindari cara-cara kekerasan. Yohanes, anak Zakaria dari kaum Esseni itu, adalah seorang utusan Tuhan yang mengabarkan akan datangnya zaman baru bagi bangsa Yahudi. Ia memproklamasikan kedatangan Kerajaan Allah (The Kingdom of God) dalam waktu dekat. Bangsa Yahudi yang hidup dalam penindasan saat itu tentu saja menyambut kedatangan Yohanes dengan antusias. Namun, Yohanes kelak mati dipancung oleh Imperium Romawi. Maka tampillah Yesus dari Nazaret, yang pernah dibaptis oleh Yohanes, melanjutkan gerakan perjuangan spiritual yang sudah dirintis Yohanes.

Seperti halnya Yohanes, Yesus juga mengajarkan tentang Kerajaan Allah. Ia bahkan Sang Raja itu sendiri, yang sudah dinubuatkan sebelumnya (Zak. 9:9). Itu sebabnya, Imperium Romawi saat itu merasa terancam kalau-kalau Yesus kelak akan melakukan makar politik. ${ }^{10}$ Apalagi orang-orang yang mengikut Yesus saat itu memang menyebut-Nya sebagai Raja Israel (Yoh. 12:13). Tapi mereka salah, karena kemudian Yesus mengatakan sendiri bahwa Ia tidak akan mendirikan kerajaanNya di dunia ini (Yoh. 18:36). Apalagi pada saat lain Yesus juga mengajarkan agar bangsa Yahudi taat kepada Kaisar Romawi dengan memberi apa yang harus diberikan kepada sang kaisar (Mat. 22:15-21).

Yesus sendiri akhirnya mati karena otoritas politik saat itu. Sepotong kalimat dalam Pengakuan Iman Rasuli yang selalu kita ucapkan dalam ibadah di gereja, "Yang menderita

${ }^{10}$ Will Durrant, Story of Civilization: Volume 3, Caesar and Christ (New York: Simon and Schuster, 1966), 554-555. 
sengsara di bawah pemerintahan Pontius Pilatus, disalibkan, mati dan dikuburkan ..." itu saja sudah menunjukkan bahwa Yesus berada di dalam sebuah sistem politik. Tapi, karena sistem politik saat itu sangat otoriter, maka secara sepihak Ia dituduh akan melakukan makar walaupun tuduhan itu sendiri tak pernah berhasil dibuktikan hingga ajal-Nya.

Atas dasar itu, lalu bagaimana menjelaskan relasi antara Yesus dan politik? Pertama, Yesus memiliki visi politik, yakni menghadirkan Kerajaan Allah. Namun bagi Yesus, Kerajaan Allah itu "ada di antara kamu" (Luk. 17:20-25), artinya di tengah kita sendiri. Jadi, Kerajaan Allah versi Yesus bukanlah sesuatu yang berwujud fisik semisal istana yang lengkap dengan angkatan bersenjata dan teritori kekuasaannya. Kerajaan Allah adalah situasi dan kondisi ketika kebenaran, keadilan dan kesejahteraan diwujudnyatakan di dalam kehidupan bersama.

Kedua, Yesus adalah seorang tokoh spiritual sekaligus tokoh politik. Kajian mendalam Erich Fromm tentang sejarah Alkitab dan gerakan-gerakan kristiani awal, dalam You Shall be As Gods (1968), menyiratkan bahwa seorang tokoh gerakan keagamaan pada hakikatnya adalah seorang tokoh politik. Agama dan politik merupakan dua aspek kehidupan yang bertalian erat satu sama lain - yang di abad-abad selanjutnya bahkan kerap bercampur-aduk dalam praktiknya, sehingga kita bisa menyimpulkan bahwa memisahkan keduanya sama sekali tidaklah mungkin.

Itulah uniknya cara berpolitik Yesus, yakni politik tanpa kekerasan. Alih-alih mengajarkan pemberontakan terhadap 
pemerintah, Yesus justru mengajarkan ketaatan, meski pemerintah itu sendiri penindas. Yesus tak pernah mendorong para pengikut-Nya untuk menggulirkan revolusi sosial. Inilah politik yang tidak berorientasi kekuasaan. ${ }^{11}$

Visi politik Yesus ini kelak dilanjutkan oleh Rasul Paulus. Dalam suratnya kepada para pengikut Kristus di Roma, Paulus juga menekankan agar Kristen "takluk kepada pemerintah", "tidak melawan pemerintah", "berbuat baik", termasuk "membayar pajak" (pasal 13 ayat 1-7). Di samping Surat Roma, dalam Perjanjian Baru juga ada beberapa nas lain yang memberi nasihat tentang bagaimana seharusnya sikap Kristen terhadap pemerintah. Dalam 1 Pet. 2:13-17, 1 Tim. 2:2, dan Titus 3:1, kita temukan berbagai unsur yang tercantum juga di dalam surat Roma. Ayat-ayat tersebut pada intinya mengajarkan ketaatan kepada pemerintah, bahkan kepada semua penguasa, yang ditempatkan di atas kita dan yang diberi tugas menghukum kejahatan, sementara kewajiban kita sendiri adalah berbuat baik. Dengan demikian dapat disimpulkan bahwa nasihat mengenai sikap Kristen terhadap pemerintah merupakan ajaran umum gereja purba.

${ }^{11}$ Namun, konteks sekarang tentu berbeda dengan konteks Yesus di abad pertama Masehi itu. Di zaman modern ini, bila kalangan Kristen masuk ke dunia politik dan mengejar kekuasaan tentu sah-sah saja. Sebab, dengan kekuasaan di tangan, kita dapat mempengaruhi proses-proses politik formal secara lebih efektif. 
Ketiga, Yesus adalah martir politik. ${ }^{12}$ Menurut Mutiara Andalas, yang merujuk pemikiran teolog Amerika Latin Jon Sobrino, kitab suci kristiani banyak membahas tema penderitaan. Yesus menangkap realitas penderitaan korban dan mencari jalan untuk membebaskan mereka. Penguasa politik, agama, dan cendekiawan di zaman Yesus cenderung menggelapkan realitas penderitaan. Solidaritas dengan korban absen dari hidup publik. Yesus berada di sisi komunitas korban yang mengalami penderitaan. Dosa mengakibatkan perpecahan dalam masyarakat. Minoritas penghuni dunia yang memiliki kekuasaan hendak menguasai meja perjamuan bersama dengan menendang keluar mayoritas warga dunia lain. Penyingkiran hidup komunitas korban dari masyarakat itu mendapat justifikasi agama. Di saat itulah Yesus hadir, membuka mata dan hati-Nya kepada korban. Ia tidak berlalu dari hadapan mereka. Sebaliknya, Ia berhenti, mendekati dan mengobati luka-luka mereka. Yesus adalah pribadi yang berani berkorban demi menghadapi realitas sosial. Bahkan Ia sendiri menjadi korban kekerasan yang paling brutal demi menawarkan kehidupan baru.

Pembahasan di atas kemudian menimbulkan beberapa pertanyaan yang bisa ditarik benang merahnya sampai ke bidang politik dewasa ini. Pertama, apakah yang dimaksud dengan "berbuat baik" itu? Kedua, apakah sesungguhnya makna "takluk" kepada pemerintah? Ketiga, jika Paulus

12 P. Mutiara Andalas, SJ, Kesucian Politik - Agama dan Politik di Tengah Krisis Kemanusiaan (Jakarta: Libri BPK Gunung Mulia, 2008), 174-177. 
menulis bahwa "pemerintah berasal dari Allah", masihkah itu relevan di negara demokrasi yang sudah mengalami modernisasi politik ke arah yang makin sekuler dan tak ada lagi pandangan tentang "kekuasaan yang sakral"? Dengan kata lain, bukankah faktanya pemerintah sekarang ini (terutama di negara-negara berbentuk republik) berasal dari rakyat, dalam arti rakyatlah yang memilih dan memberi mandat kepada mereka untuk berkuasa?

\section{TEORI KEKUASAAN NEGARA}

Surat Paulus kepada para pengikut Kristus di Roma harus diinterpretasi secara kritis dan kontekstual agar tak menimbulkan pemikiran-pemikiran naif dalam memandang hubungan gereja dan negara. Khususnya terhadap Pasal 13, gereja-gereja harus belajar memahami sejarah pemikiran politik yang bergulir dialektis sejak zaman dulu hingga kini. Secara khusus, yang perlu dipahami adalah jawaban atas pertanyaan ini: dari manakah negara memperoleh kekuasaannya?

Sejak zaman Yunani Kuno, sebelum Yesus lahir, persoalan kekuasaan negara itu memang sudah menjadi perdebatan. Dua pemikir besar di zaman itu, Plato dan Aristoteles, mengatakan bahwa negara membutuhkan kekuasaan mutlak agar dapat mendidik rakyatnya dengan nilai-nilai moral yang rasional. ${ }^{13}$

Memasuki zaman Masehi, konsep kekuasaan mutlak negara itu kemudian diambil-alih oleh agama Kristen. Terlebih

${ }^{13}$ George Sabine, Teori-teori Politik, terj. Soewarno Hadiatmodjo (Jakarta: Bina Cipta, 1977), 7. 
sejak agama ini berkembang menjadi agama yang mapan di bawah pemerintahan Raja Konstantin Agung (305-337). Sebelumnya, agama Kristen merupakan agama yang dikejarkejar untuk ditumpas oleh Imperium Romawi. Agama Kristen kemudian memberikan keabsahan kepada raja-raja Kristen yang memerintah dengan kekuasaan yang hampir mutlak. Kekuasaan para raja ini hanya dibatasi oleh kekuasaan gereja. ${ }^{14}$

Pengaruh agama kemudian menjadi semakin kuat, sehingga seorang raja akan mengalami krisis legitimasi kekuasaan jika tidak diberkati gereja. Sebaliknya, negara yang diberkati oleh gereja dianggap sebagai negara yang diberkati oleh Tuhan. Karena itulah ia layak dipatuhi oleh rakyatnya. Kekuasaan raja, karena itu pula, dianggap sebagai perpanjangan kekuasaan Tuhan atas alam semesta. Kekuasaannya adalah kekuasaan ilahi. Selanjutnya, posisi gereja menjadi lebih tinggi daripada posisi negara. Gereja yang diwakili Paus menjadi lebih berkuasa daripada raja-raja Kristen yang memerintah di daratan Eropa saat itu. Gereja adalah wakil Tuhan untuk persoalan keselamatan di akhirat, sedangkan negara adalah wakil gereja untuk mengatur kehidupan di dunia. Karena itu, sudah sepatutnyalah jika kekuasaan gereja lebih besar daripada kekuasaan negara.

Memasuki abad ke-16, timbullah keraguan orang akan kekuasaan gereja yang berlebihan itu. Apalagi saat itu banyak

${ }_{14}^{14}$ J.J. von Schmid, Ahli-Ahli Pikir Besar tentang Negara dan Hukum: Dari Plato sampai Kant, terj. R. Wiratno, Djamaluddin DT. Simangkuto, dan Djamadi, (Jakarta: Pembangunan, 1980), 73-74. 
pemimpin gereja yang melakukan penyimpangan dalam hal ajaran dan praktik kehidupan bergereja. Misalnya saja surat pengampunan dosa yang diperjualbelikan. Pendeknya, Paus terlalu mendominasi kehidupan masyarakat dan tak sungguhsungguh menghargai pemerintah. Gereja telah merampas hakhak pemerintah, sehingga terseret dalam hal-hal duniawi seperti politik, peperangan, dan pengurusan harta-benda. Disebabkan keadaan gereja yang makin kacau itu, tampillah seorang rahib muda Jerman bernama Martin Luther (14831546). Ia sangat gencar mengkritik pelbagai ajaran dan praktik kehidupan gereja yang dianggapnya telah jauh menyimpang dari kebenaran Alkitab. Ia juga mengajukan pokok-pokok pikirannya tentang reformasi gereja, di hadapan sivitas akademika Universitas Wittenberg, pada 31 Oktober 1517.

Pada intinya pemikiran Luther menekankan pentingnya kebebasan individu dalam berhubungan dengan Tuhan. Dalam hal politik, Luther mengajarkan agar orang percaya takluk kepada pemerintah dan taat kepada hukum-hukumnya. Namun, hendaknya itu dilakukan secara sukarela dan bukan karena dipaksa dengan kekerasan. Tapi karena tidak semua orang baik, maka negara juga diperlukan sebagai wadah pemerintahan Tuhan di dunia. Orang baik dapat diperintah dengan Roh Kudus, sedangkan orang jahat harus diperintah dengan pedang (melalui pangeran, raja, dan para hakim) dan dengan cara kekerasan. Jadi, gereja dan negara harus berjalan bersamaan di dunia ini. Lalu, bagaimana jika pemerintahan 
duniawi itu bertindak lalim? Menurut Luther, pemerintah sama sekali tak boleh ditentang. ${ }^{15}$ Itulah sebabnya, etika sosial Luther kelak disebut defeatis (mengalah) dan quietist (pasif, menolak aksi).

Selanjutnya tampillah John Calvin (1509-1564), dari Perancis. Ia sangat menekankan pentingnya moralitas dan disiplin hidup (etos kerja) orang-orang yang percaya kepada Tuhan. ${ }^{16}$ Dalam hal politik, Calvin menolak ajaran kaum reformasi radikal bahwa orang Kristen tidak memerlukan lagi adanya negara. Menurut dia, selama manusia hidup di dunia ini, negara harus dipandang sebagai anugerah Tuhan untuk mengusahakan kesejahteraan bagi masyarakat. Atas dasar itu Calvin menolak bahwa orang-orang percaya tidak harus takluk kepada pemerintah. Hukum yang dibuat pemerintah haruslah ditaati demi mendatangkan keadilan. Itulah sebabnya, negara dapat menggunakan kekerasan dan paksaan sepanjang hal itu diperlukan.

Namun, bagaimana jika pemerintah korup dan sewenangwenang terhadap rakyatnya? Calvin menjawab, karena pemerintah adalah hamba Tuhan, maka perlawanan terhadap pemerintah yang lalim sama halnya dengan perlawanan terhadap Tuhan. Yang boleh dilakukan rakyat hanyalah berdoa. Terhadap pemerintah yang lalim, Tuhan sendiri akan memakai cara-cara tertentu untuk memusnahkan para penguasa yang

${ }^{15}$ Lihat Christiaan De Jonge, Apa Itu Calvinisme? (Jakarta: BPK Gunung Mulia, 1998).

16 Ibid. 
korup itu (misalnya melalui pemberontakan di dalam negeri atau penyerangan musuh dari luar). Tapi, kata Calvin lagi, kalau semua cara itu gagal mengendalikan seorang raja yang lalim, dengan sangat terpaksa boleh dipakai kekerasan. Namun, hal itu hanya boleh dilakukan atas prakarsa mereka yang diberi wewenang dalam hukum negara untuk ikut memerintah. Sedangkan masyarakat, secara pribadi-pribadi, dilarang untuk memberontak.

Dengan meluasnya pemikiran-pemikiran reformator itu, dari Skotlandia kemudian tampillah seorang rohaniwan bernama John Knox (1513-1572). Perihal ketaatan rakyat terhadap pemerintah, Knox menentang Calvin karena kepasifannya. Menurut Knox, tugas setiap orang percaya adalah mengoreksi raja (penguasa) jika ia bertentangan dengan kehendak Tuhan atau melakukan pelbagai tindakan yang tidak mempermuliakan nama Tuhan. Jadi, ia secara tegas menolak pemikiran Calvin bahwa pemberontakan rakyat terhadap pemerintah selalu salah. Tindakan itu diperlukan, menurut Knox, dalam konteks reformasi gereja. ${ }^{17}$

Tak pelak, gerakan reformasi gereja saat itu merupakan peristiwa penting yang berdampak politis sangat besar. Hal ini tidak mengherankan jika disadari betapa besarnya peranan gereja dalam seluruh kehidupan masyarakat pada masa itu. Setiap goncangan di gereja langsung terasa dalam seluruh kehidupan masyarakat dan mengundang reaksi keras dari pemerintah. Itulah sebabnya para reformator diperhadapkan

17 Ibid. 
dengan konsekuensi politik dari reformasi mereka. Mereka dipaksa untuk menentukan sikap terhadap tatanan politik pada zaman itu dan memikirkan bagaimana hubungan gereja yang diperbarui dengan pemerintah dan negara.

Selanjutnya benih-benih perlawanan yang terkandung dalam pemikiran para reformator itu dikembangkan oleh para pemikir yang dikenal sebagai kaum Monarchomacha (artinya: kaum pembantah). Kelompok yang berkembang pada akhir abad ke-16 ini mula-mula mendasarkan dirinya pada kritikkritik yang memakai kaidah-kaidah agama Kristen. Persoalan yang mereka lontarkan adalah, bila raja memperoleh kekuasaannya dari gereja, dan raja kemudian melanggar kaidah-kaidah agama (tetapi gereja tetap merestuinya), haruskah raja yang demikian dipatuhi terus? Mana yang lebih penting untuk dipatuhi: raja, yang diberkati oleh gereja, atau kaidah-kaidah agama, yang tidak selalu berarti gereja? Dengan dipertentangkannya kaidah-kaidah agama dengan kekuasaan seorang raja (termasuk gereja yang memberkatinya), dengan demikian kaum Monarchomacha telah meletakkan dasar-dasar untuk meragukan sekaligus kekuasaan mutlak raja dan gereja. ${ }^{18}$

Hal yang penting dalam hal ini adalah dipisahkannya kaidah agama dari kekuasaan gereja. Orang di luar gereja juga punya kemampuan untuk melakukan interpretasi tentang apa yang disebut sebagai kaidah agama. Jadi, interpretasi tentang kaidah-kaidah agama itu bukan lagi menjadi monopoli gereja. Pemikiran semacam ini makin berkembang. Kaum

${ }^{18}$ Lihat Schmid, Ahli-ahli Pikir Besar tentang Negara dan Hukum. 
Monarchomacha yang muncul belakangan tak lagi membatasi diri pada kaidah-kaidah agama saja sebagai dasar-dasar perlawanannya. Mereka juga mulai bicara tentang hak-hak rakyat, dengan mengajukan pertanyaan: dapatkah rakyat melakukan perlawanan terhadap raja, jika sang raja melakukan penindasan terhadap mereka, sekalipun sang raja tidak melanggar kaidah-kaidah agama?

Maka, dimulailah sekularisasi kekuasaan negara. ${ }^{19}$ Saat itu sebenarnya mulai muncul ide-ide tentang kedaulatan rakyat. Brutus (nama samaran), misalnya, pada 1579, menulis sebuah buku berjudul Vindiciae Contra Tyrannos, yang banyak membahas tentang kedaulatan rakyat. Ia menyatakan, meskipun seorang raja dipilih oleh Tuhan, tetapi ia diangkat berdasarkan persetujuan rakyatnya. Karena itu seorang raja tak boleh memerintah dengan sewenang-wenang. Jika itu terjadi, setiap orang berhak untuk melawannya.

Masuk ke Zaman Pencerahan, muncullah para pemikir yang berupaya menjelaskan kekuasaan negara secara rasional dan pragmatis (McDonald, 1968). ${ }^{20}$ Misalnya Thomas Hobbes (1588-1679), seorang filsuf Inggris, yang berupaya membela kekuasaan mutlak negara dengan alasan non-agama. Menurut dia, negara memang harus memiliki kekuasaan yang besar. Karena jika tidak, keadaan masyarakat akan sangat kacau

19 Ibid.

${ }^{20}$ Lihat Lee Cameron McDonald, Western Political Theory, from Machiavelli to Burke (San Diego, California: Harcourt Brace Jovanovich, 1968), 194-207. 
disebabkan setiap orang saling berperang demi memperjuangkan kepentingannya sendiri-sendiri. Saat itu mulai muncul tesis bahwa negara merupakan wakil dari kepentingan umum, sedangkan masyarakat hanya mewakili kepentingan individu atau kelompok secara terpecah-pecah.

Pendapat Hobbes itu kemudian ditentang oleh John Locke (1632-1704), rekan senegaranya. Menurut dia, kekuasaan negara haruslah dibatasi. Batas itu adalah hak-hak alamiah yang melekat di dalam diri manusia sejak kelahirannya. Yaitu, hak atas kehidupan, hak atas kemerdekaan, dan hak atas milik pribadi. Bagi Locke, negara ada justru untuk melindungi hakhak alamiah yang tak terpisahkan itu. Kalau negara tidak melakukannya, maka merupakan hak individu untuk melawannya. Kelak, pemikiran Locke dianggap sebagai awal bagi berkembangnya gagasan-gagasan tentang hak asasi manusia (HAM).

Setelah Locke, tampillah Montesquieu (1689-1775) dari Perancis. Pemikirannya yang terkenal adalah Trias Politica, perihal pemisahan kekuasaan antara lembaga eksekutif, legislatif, dan yudikatif. Menurut dia, pemisahan kekuasaan itu penting agar tak terjadi kesewenang-wenangan oleh orangorang yang diserahi kekuasaan rakyat dalam penyelenggaraan negara. Berikutnya, dari negara yang sama, tampillah JeanJacques Rousseau (1712-1778), seorang filsuf yang sangat besar pengaruhnya bagi perkembangan pemikiran politik zaman itu. Ia melontarkan gagasan tentang negara sebagai res publika (republik), yang berarti "urusan publik". Negara tak lagi merupakan sesuatu yang asing, yang hanya dimiliki raja atau 
sekelompok orang saja, melainkan milik semua. Bagi Rousseau, itulah negara yang sah: republik. Di dalamnya, rakyat berdaulat dan ikut mengurusi persoalan-persoalan negara.

Sejak itulah gagasan tentang demokrasi sebagai sistem politik yang menekankan kedaulatan rakyat mulai berkembang. Selanjutnya, abad ke-19, dimulailah Zaman Liberal, dengan pemikiran-pemikiran yang menekankan pentingnya kebebasan individual. Negara, menurut para pemikir Liberalisme Klasik ini, hanya berperan sebagai "penjaga malam" yang mengurusi masalah-masalah keamanan saja. Di Perancis, konsep kebebasan individu ini dikenal sebagai laissez-faire (artinya: biarkan saja). Jadi, negara dilarang ikut campur dalam kehidupan warganya. Kekuasaan negara kecil sekali. Namun kemudian, peran negara yang minimal itu dirasakan tak memadai. Dalam bidang ekonomi, kebebasan individual itu justru kian memperlebar kesenjangan antara golongan yang kaya dan miskin. Maka, negara pun kemudian diberi kekuasaan dan peran yang lebih besar untuk mencampuri urusan-urusan warganya. Tujuannya, demi menciptakan kesejahteraan masyarakat. Namun, kebebasan individual tetaplah dihargai. Itulah zaman yang disebut NeoLiberal, yang dimulai pada awal abad ke-20, dengan pemikiranpemikiran yang disebut Liberalisme Modern. ${ }^{21}$

Di antara kedua aliran pemikiran itu, muncullah Karl Marx dengan tafsiran barunya tentang negara dan kekuasaan.

${ }^{21}$ J. Salwyn Schapiro, Liberalism: Its Meaning and History (Princeton:

N.J. Van Nostrand, 1958), 14. 
Ia memakai teori Hegel (tentang dialektika sejarah), yang sudah diubahnya dengan menyatakan bahwa tujuan sejarah adalah terciptanya masyarakat komunis yang harmonis. Marx mengatakan bahwa perjuangan kelas adalah motor penggerak sejarah. Negara, yang selama ini dijadikan alat oleh kelas pemilik modal, harus dikuasai oleh kelas buruh. Setelah itu kaum buruhlah yang dengan kemampuannya bertanggung jawab untuk merealisasikan terbentuknya masyarakat komunis tanpa kelas dan tanpa pemilikan pribadi itu. ${ }^{22}$

Pemikiran Marx, boleh dibilang, hanya berkembang di beberapa negara saja. Uni Soviet sendiri, negara komunis terbesar yang membangun sistem politiknya di atas pemikiran Marxis, terbukti gagal hingga akhirnya bubar (1991). Pemikiran yang justru kian populer, bahkan kian menjadi tren dunia dewasa ini, adalah demokrasi sebagai suatu sistem politik yang meletakkan kedaulatan di tangan rakyat. Rakyatlah yang berkuasa atas negara, sehingga rakyat pulalah yang berhak menentukan para pemimpin untuk diserahi kekuasaan menjalankan roda pemerintahan. Atas dasar itu, maka para pemimpin haruslah senantiasa memberi pertanggungjawaban kepada rakyat. Dan jika mereka dinilai gagal atau telah melakukan penyimpangan, rakyat berhak mengkritik, memprotes, bahkan menentangnya. Rakyat juga berhak menggantikannya, melalui sebuah ajang pemilu yang terselenggara secara periodik.

${ }^{22}$ Lihat McDonald, Western Political Theory, 194-207. 
Jadi, jelaslah bahwa kekuasaan para pemimpin di negara demokratis tidak berasal dari Tuhan. Kekuasaan itu bersumber dari rakyat. Sebab tanpa rakyat tak ada negara. Itulah sebabnya rakyat berhak untuk mengawasi jalannya pemerintahan dan berpartisipasi di dalam proses pembuatan kebijakan negara yang berkait dengan hajat hidup rakyat. Pendeknya, rakyat sungguh-sungguh dihargai di negara semacam ini. Setiap orang dipandang setara dalam derajat dan kesempatan. Mereka bebas menyatakan pendapat, membentuk kelompok kepentingan maupun partai politik dan saling bersaing untuk menempatkan pemimpin-pemimpin pilihan mereka pada posisi-posisi strategis pembuat kebijakan atau pengambil keputusan bagi rakyat.

\section{POLITIK KRISTEN DI INDONESIA}

Peran Kristen dalam perpolitikan di negara ini selama lebih dari setengah abad rasanya tak terlalu dapat dibanggakan. Selama beberapa dekade sejak Proklamasi Kemerdekaan (1945) mungkin masih ada beberapa tokoh, kelompok atau gerakan Kristen yang patut dikemukakan karena kontribusi positifnya di dalam kehidupan bernegaraberbangsa. Sebutlah, misalnya, Dr. G.S.S.J. Ratu Langie, Dr. T.S. Gunung Moelia, Mr. Amir Sjarifoeddin, dan Dr. Johannes Leimena untuk individu; sedangkan untuk kelompok atau gerakan, antara lain Parkindo (Partai Kristen Indonesia) dan PKN (Partai Kristen Nasional). Hingga beberapa dekade di era Orde Baru pun masih ada tokoh Kristen yang sangat disegani di aras nasional, yakni Dr. T.B. Simatupang, seorang 
purnawirawan militer yang pemikiran-pemikiran teologi sosialpolitik dan pertahanan-keamanannya dipuji banyak orang. Tetapi, setelah mereka semua berlalu dan rezim Soeharto makin dominan dan represif, gerakan politik Kristen pun kian meredup.

Pasca-Soeharto, seiring reformasi dan demokratisasi yang bergulir, sebagian Kristen pun mulai terjangkiti euforia berpolitik. Sebagian mereka masuk menjadi kader di sejumlah partai nasionalis, sementara yang lainnya memilih untuk mendirikan partai politik sendiri dengan mengusung bendera Kristen. Pertanyaannya, tepatkah itu untuk Indonesia yang mayoritas rakyatnya beragama Islam? Jelas tidak. Apalagi, seperti sudah dijelaskan di atas, berpolitik itu haruslah berorientasi untuk kebaikan umum. Jadi, jika agama diusung tinggi-tinggi dalam berpolitik, maka yang tercipta justru adalah "batas dan jarak". Akan ada pihak dan kalangan tertentu di masyarakat yang merasa terhalangi untuk mendukung apalagi bergabung dengan partai tersebut.

Pertanyaan kedua, apakah Kristen harus ikut berpolitik? Saya ingin menjawabnya dengan merujuk pemikiran Dr. Johannes Leimena (1905-1977), salah seorang inisiator Sumpah Pemuda 1928 dan salah satu tokoh Kristen terkemuka di era Soekarno. Menurut dia, Kristen di Indonesia memiliki dwikewargaan (dual citizenhip). Secara kritis Leimena memikirkan tentang bagaimana kedudukan warga gereja dan warga negara yang "paradoksal" di Indonesia, dikaitkan dengan makna kehadiran Kristen di negeri ini sebagai sebuah "karunia" (Gabe) yang harus disikapi dalam wujud kerja sama yang kritis solider 
dengan sesama warga negara Indonesia lainnya; dalam arti to share and share alike, sebagai suatu pertanggungjawaban (Aufgabe) kepada Sang Pemberi, yaitu Tuhan Allah sendiri, demi keutuhan negara dan bangsa berdasarkan Pancasila sebagai ideologi yang pluralis, sekuler, integratif, sentripetal dan final. ${ }^{23}$ Jadi bagi Leimena, menjadi Kristen juga sama pentingnya dengan menjadi warga negara Indonesia yang bertanggung jawab pada saat bersamaan. Karena itulah ia selalu menekankan agar kehadiran Kristen bisa membawa keharmonisan dan berkat bagi segenap bangsa.

Atas dasar itu maka bagi Kristen, berpolitik seharusnya merupakan panggilan. Hanya saja di sini perlu diperhatikan dua kategori tentang berpolitik: 1) berpolitik moral (etik); 2) berpolitik praktis. Yang pertama merupakan upaya mempengaruhi kehidupan publik dan atau kehidupan bernegara melalui tindakan bersuara (mengkritisi dan atau memberi masukan kepada pihak-pihak yang memegang kekuasaan melalui pelbagai media dan saluran) tanpa berpikir untuk mencari kekuasaan itu sendiri. Sedangkan yang kedua merupakan upaya mempengaruhi kehidupan publik dan atau kehidupan bernegara melalui partai politik, yang karenanya juga selalu berorientasi untuk meraih kekuasaan. Berpolitik

${ }^{23}$ Lihat P.D. Latuihamallo, Kewarganegaraan yang Bertanggung Jawab, Mengenang Dr. J. Leimena (Jakarta: BPK Gunung Mulia, 1980). Lihat juga Flip P.B. Litaay, Pemikiran Sosial Johannes Leimena tentang Dwi-Kewargaan di Indonesia (Salatiga: Satya Wacana University Press bekerja sama dengan Program Pascasarjana Program Studi Sosiologi Agama UKSW Salatiga, 2007). 
moral merupakan hak asasi setiap orang (termasuk Kristen) dan selayaknya digunakan dengan semaksimal mungkin. Sedangkan berpolitik praktis seharusnya menjadi pertimbangan bagi mereka yang betul-betul merasa memiliki kompetensi di bidang ini, termasuk di antaranya adalah keberanian bersuara lantang dan beradu argumen dengan banyak orang.

Intinya hanya itu. Tinggal dilengkapi dengan ini: bahwa berpolitik yang kristiani haruslah etis dan logis. Dengan etis berarti cara dan strateginya haruslah sesuai dengan nilai-nilai kristiani. Itu berarti praktik money politics haruslah dijauhkan. Sedangkan logis menunjukkan bahwa Kristen berpolitik secara cerdas, bukan untuk kepentingan golongan tertentu, melainkan untuk kepentingan bersama.

\section{PILPRES 2014 DAN FAKTOR AGAMA}

Sejumlah ilmuwan politik seperti Juan Linz, G. Bingham Powell, Jr, dan Robert Dahl menyimpulkan ada lima indikator untuk mengamati apakah suatu negara telah layak dikategorikan sebagai negara yang demokratis atau tidak. Salah satunya adalah pemilu. ${ }^{24}$ Terkait dengan itu Indonesia telah berulang kali menyelenggarakan pemilu, baik pemilu untuk memilih para calon anggota legislatif (pileg), calon presiden dan wakil presiden (pilpres), juga calon kepala daerah (pilkada). Berdasarkan realitas yang ada dalam setiap pemilu

${ }^{24}$ Dikutip oleh Affan Gaffar, Politik Indonesia: Transisi Menuju Demokrasi (Yogyakarta: Pustaka Pelajar, 1999), 3-10. 
tersebut, tidak sedikit ilmuwan, pengamat dan praktisi politik yang mengatakan bahwa pemilu pertama yang diselenggarakan pada 1955 merupakan pemilu terbaik. Dalam pemilu saat itu tidak ada praktik menyogok para calon pemilih, partisipasi politik rakyat tinggi, dan tidak ada bentrokan antarkonstituen partai kontestan pemilu. ${ }^{25}$ Demikian disampaikan oleh Ketua Majelis Syuro Partai Bulan Bintang (PBB) yang juga pakar hukum tata-negara, Yusril Ihza Mahendra. ${ }^{26}$ Walaupun saat itu adalah fase ideologis yang di dalamnya terdapat berbagai benturan pemikiran ideologis yang sangat keras antara satu tokoh partai dengan tokoh partai yang lain, tidak ada setetes pun darah tercecer. Pemilu tetap terselenggara secara damai.

Bagaimana dengan pemilu yang baru lalu, Pemilu 2014? Pemilu yang diselenggarakan dengan berbagai bekal pengalaman dari pemilu-pemilu sebelumnya itu, dengan persiapan yang telah dilakukan secara lebih matang, seharusnya menjadi pemilu terbaik. Namun, kenyataan berbicara sebaliknya. Pemilu 2014, baik pileg maupun pilpres, disebut-sebut banyak pihak dan kalangan sebagai pemilu terburuk sepanjang sejarah republik ini berdiri. Selain penyediaan logistik pemilu yang berantakan, pelanggaran aturan main pemilu terjadi secara masif dan dilakukan oleh seluruh komponen atau pihak yang terlibat dalam

25 Eep Saefulloh Fatah, Mencintai Indonesia dengan Amal: Refleksi atas Fase Awal Demokratisasi (Jakarta: Penerbit Republika, 2004), 67.

${ }^{26}$ http://news.detik.com, 24 April 2010. 
penyelenggaraan pemilu, baik rakyat pemilih, caleg, partai politik maupun penyelenggara pemilu itu sendiri. Belum lagi maraknya politik uang dan kampanye hitam di mana-mana, baik yang dilakukan oleh orang-orang partai, para caleg, maupun publik pendukungnya, baik yang terjadi di dunia nyata maupun dunia maya. ${ }^{27}$ Apalagi di ajang pilpres, harus diakui bahwa rakyat terbelah menjadi dua kubu antara pendukung pasangan Jokowi-JK dan Prabowo-Hatta. Pembelahan tersebut bahkan memicu konflik cukup besar, terutama di dunia maya, yang sampai sekarang masih bisa terlihat semisal di Facebook.

Mengapa pembelahan itu dapat terjadi? Salah satu jawabannya adalah: karena faktor agama. Dengan kata lain: agama dibawa-bawa ke dalam politik. Tapi lucunya, dalam konteks ini bukan Islam dan Kristen yang saling bertentangan karena pilihan pasangan capres-cawapres, melainkan pilihan pada pasangan tertentu yang diberi pembenaran sebagai "bisikan Roh Kudus" atau "sesuai dengan iman kristiani". Siapa pasangan tersebut? Kita sudah tahu jawabannya, yakni Prabowo-Hatta. Tapi secara lebih khusus yang diberi penekanan di sini adalah Prabowo Subianto, sebagai capres.

\section{INDONESIA BUKAN NEGARA AGAMA}

Membahas Prabowo tak bisa tidak harus membahas partainya: Gerindra. Terkait itu peneliti dari Pusat Litbang

${ }^{27}$ http://surabaya.tribunnews.com, 24 Mei 2014. 
Kemasyarakatan dan Kebudayaan LIPI, Ahmad Najib Burhani, menegaskan negara akan makin terlibat menjadi hakim dalam penentuan keyakinan/kelompok jika Prabowo Subianto nanti terpilih jadi Presiden RI. "Kita harapkan ke depan kaum minoritas mendapatkan harapan yang lebih cerah. Kecuali presidennya berasal dari yang saya sebut tadi (Prabowo) maka akan bahaya terhadap komunitas minoritas yang akan datang," kata Najib. ${ }^{28}$

Najib mengutip "Manifesto Perjuangan Partai Gerindra", butir 11, dalam bidang agama: "Pemerintah/negara wajib mengatur kebebasan di dalam menjalankan agama atau kepercayaan. Negara juga dituntut untuk menjamin kemurnian ajaran agama yang diakui oleh negara dari segala bentuk penistaan dan penyelewengan dari ajaran agama." Lalu apa konsekuensi manifesto ini jika Prabowo terpilih jadi Presiden? Menurut Najib, peran negara akan makin terlibat dan menjadi hakim dalam penentuan keyakinan/kelompok keagamaan yang ortodoks (benar) dan heterodoks (sesat) di Indonesia. “Dia bisa bergerak melampaui SBY dalam intervensi keyakinan keagamaan", kata Najib. Menurut dia, kelompok yang senang dengan ini adalah kelompok yang sekarang menjadi mainstream atau sering mengklaim mewakili suara mayoritas seperti MUI, FPI, dan FUI. "Jika mengikuti logika ini maka partai berideologi Islam seperti PPP, PKS, dan PBB akan bergabung

${ }^{28}$ Diambil dari Najib dalam Talk Show DPD RI bertopik "Peta Politik di Senayan PascaPemilu” di gedung DPD/MPR RI Jakarta, 25 April 2014. 
dengan Gerindra", kata Najib. ${ }^{29}$

Pernyataan Najib mendasari saya untuk mengajukan pertanyaan ini: sesungguhnya negara apakah Indonesia ini? Di satu sisi, sejak Indonesia merdeka, negara ini telah didesain menjadi negara hukum (rechtstaat). Tapi di sisi lain, Indonesia adalah negara yang ambigu: bukan negara agama (teokrasi) tapi dilandasi dengan agama. Maka tidaklah heran jika negara seakan berwenang mengintervensi agama, yang secara sosiologis merupakan ranah privat (privacy sphere). Merujuk pemikiran Bryan S. Turner ${ }^{30}$, tidakkah di era modern ini tindakan negara seperti itu seharusnya sudah diusangkan? Atas dasar itu maka negara harus memandang rakyatnya sebagai warga negara (citizen), bukan umat.

Indonesia sudah menjadi negara demokratis ketiga terbesar di dunia, seperti yang diakui oleh International Association of Political Consultants melalui pemberian Medali Demokrasi pada 12 November 2007. Namun, mengapa pemerintah masih kerap mengintervensi agama? Tidakkah demokrasi merupakan ciri dari negara yang sudah modern secara politik? Dan bukankah di negara modern seperti itu, politik (negara atau pemerintah) dan agama merupakan dua ranah yang seharusnya saling menjaga jarak? Teori-teori pembangunan politik mengatakan: negara yang kian

${ }^{29}$ Dikutip oleh Victor Silaen, "Indonesia bukan Negara Agama", Forum Keadilan No. 04, 19-25 Mei 2014, 46-47.

${ }^{30}$ Bryan S. Turner, Religion and Social Theory (California: Sage Publication, 1991), 183. 
mengalami reformasi dan demokratisasi seiring waktu niscaya kian bertumpu pada rasionalitas dan sekularisme. ${ }^{31}$ Dengan rasionalitas berarti semua pertimbangan kalkulatif makin dikedepankan. Sedangkan sekularisme bukan berarti menjauhkan agama-agama dari kehidupan, melainkan menjaga jarak politik agar agama-agama tidak secara leluasa dapat mengintervensi urusan-urusan bernegara. Begitupun sebaliknya, agar negara tidak secara leluasa dapat mengintervensi urusan-urusan agama dan keberagamaan.

Benar bahwa Indonesia adalah bangsa yang religius, tapi Indonesia bukan negara agama. Dasar negara ini adalah Pancasila, yang sila pertamanya menyebut "Ketuhanan". Tapi itu bukan berarti negara boleh menjadikan perihal "Ketuhanan" sebagai ranah yang harus dimasuki dan diurusnya. Sebab "Ketuhanan" adalah soal ajaran agama, dan ajaran agama manapun tak sekali-kali boleh diintervensi negara.

Berpijak pada pemikiran itulah maka saya ingin mengajukan pertanyaan yang lain: mengapa Gerindra melalui manifesto perjuangan partainya, dalam bidang agama, menyebut-nyebut "negara juga dituntut untuk menjamin kemurnian ajaran agama yang diakui oleh negara dari segala bentuk penistaan dan penyelewengan dari ajaran agama"? Ada beberapa keberatan yang dapat dikemukakan terhadap

${ }^{31}$ Lihat Gabriel A. Almond dan G. Bingham Powell, Jr., Comparative Politics, edisi kedua (Boston dan Toronto: Little and Brown Company, 1978), 37-39. 
manifesto tersebut. Pertama, apa yang dimaksud dengan "kemurnian ajaran agama"? Kedua, sesungguhnya secara teologis dan sosiologis, tepatkah agama-agama dikategorikan sebagai "agama yang diakui" dan "agama yang tidak diakui" negara? Sebab, berapa sesungguhnya jumlah agama di Indonesia saja kita tak dapat memastikannya. Lalu bagaimana kategori itu dapat diterima kebenarannya secara teologis dan sosiologis? Ketiga, sesungguhnya adakah pihak di negara ini yang berwenang menilai suatu keyakinan agama sebagai "tidak murni"? Keempat, adakah dasar hukum yang mengatur kewenangan untuk melakukan penilaian tersebut? Kelima, bukankah soal tidak murninya suatu keyakinan agama bersifat multi-interpretable dan karenanya terbuka untuk diperdebatkan? Keenam, bagaimana jika umat beragama (dan pimpinannya) yang dinilai "tidak murni" oleh negara itu bersikukuh untuk "tidak mau dimurnikan"?

Misalkan, dalam konteks ini agama yang dinilai "tidak murni" itu adalah Ahmadiyah. Maka pertanyaan ketujuh: apakah karena Ahmadiyah tetap bersiteguh "menolak untuk dimurnikan" maka Ahmadiyah sebagai organisasi keumatan harus dilarang beraktivitas sesuai keyakinannya? Kedelapan, apa dasar hukumnya mengeluarkan larangan tersebut? Apakah Ahmadiyah terbukti telah melanggar hukum, misalnya melakukan tindakan-tindakan kriminal atau menimbulkan kekacauan di tengah masyarakat? Sebab, adalah fakta bahwa beberapa organisasi kemasyarakatan (ormas) tertentu selama ini telah berulang kali melakukan tindakan yang menimbulkan keresahan di tengah masyarakat. Tetapi, mengapa organisasi- 
organisasi tersebut hingga kini masih dibiarkan eksis?

Majelis Ulama Indonesia (MUI) Kabupaten Ciamis barubaru ini meminta jamaah Ahmadiyah menghentikan segala bentuk kegiatan di Mesjid Nur Khilafat, Ciamis. Permintaan itu disampaikan melalui surat yang ditandatangani oleh Ketua dan Sekretaris MUI Kabupaten Ciamis, 23 April 2014 yang lalu. Ketua MUI Kabupaten Ciamis, Achmad Hidayat, menggunakan Surat Keputusan Bersama Nomor 3 Tahun 2008 yang dikeluarkan oleh Menteri Agama, Jaksa Agung dan Menteri Dalam Negeri sebagai dasar keputusan mengeluarkan imbauan tersebut. Salah satu butir dari SKB itu, Ahmadiyah diminta menghentikan semua kegiatan yang tidak sesuai dengan penafsiran agama Islam pada umumnya. Tapi, Mubaligh Ahmadiyah Ciamis Syaiful Uyun mengatakan, pihaknya menolak imbauan tersebut. Menurut dia, imbauan tersebut masuk dalam kategori menghalang-halangi warga negara untuk beribadah dan itu berarti melawan konstitusi negara UUD 1945. "Kalau sampai menutup masjid buat kami ini tindakan main hakim sendiri. Apabila ada keberatan silahkan secara prosedural melalui pemerintah pusat," ujar Uyun.

Keberatan terhadap larangan pemerintah terhadap kegiatan Ahmadiyah, apalagi sampai membubarkan kelompok itu, pernah disampaikan oleh Direktur Eksekutif Reform Institute Yudi Latif. "Kalau melarang atau membubarkan, pemerintah justru melanggar konstitusi," katanya. ${ }^{32}$ Pemerintah

${ }^{32}$ http://Tempo Interaktif, 18 April 2008. 
tidak etis jika melarang Ahmadiyah, karena berarti legitimasi negara didasarkan pada agama, padahal Indonesia bukan negara agama. Menurut Latif, persoalan Ahmadiyah merupakan persoalan internal umat Islam, sehingga negara tak perlu campur tangan. "Kalau MUI tidak sepakat, silakan. Tapi MUI atau lembaga ulama lainnya tidak dalam kapasitas meminta negara membubarkan Ahmadiyah, karena ini menyangkut hak warga negara," katanya lagi.

Pertanyaan terakhir: bukankah Gerindra tidak termasuk partai yang berbasis agama? Tetapi, mengapa Gerindra terkesan berkepentingan sekali mengurusi agama?

Pertanyaan-pertanyaan ini jelas layak dijadikan pertimbangan untuk meragukan Prabowo sebagai capres Indonesia yang benar-benar siap mendukung dasar negara Pancasila dan semboyan Bhineka Tunggal Ika. Apalagi di sisi lain, Prabowo juga disebut-sebut sebagai "panglima perang umat Islam" oleh sejumlah organisasi kemasyarakatan Islam di Yogyakarta $^{33}$. Tidakkah itu berbahaya bagi kemajemukan Indonesia?

\section{KENAIFAN PGPI}

Menjelang pilpres, ada seorang pendeta yang begitu menggebu-gebunya mengkampanyekan capres Prabowo di

33 Istman M.P., “Ormas Islam Klaim Prabowo Panglima Perang”, Tempo.com, 1 Juli 2014, http://www.tempo.co/read/news/2014/07/01/078589443/Ormas-Islam-KlaimPrabowo-Panglima-Perang. 
berbagai acara gerejawi. Bukan hanya di gerejanya (Gereja Bethel Indonesia Mawar Saron, Jakarta Utara), bahkan di gereja-gereja lain pun dia tak malu-malu "mewajibkan" jemaat untuk memilihnya nanti dalam pilpres. Dialah Pdt. Dr. Jacob Nahuway, MA, seorang gembala sidang, ketua sinode, sekaligus ketua lembaga gerejawi aras nasional yang bernama Persekutuan Gereja-gereja Pentakosta Indonesia (PGPI). Selain mengaku mendapatkan "bisikan Roh Kudus"34, menjelang pilpres ia juga menerbitkan sepucuk surat dengan kop surat resmi PGPI yang ditandatanganinya bersama Sekretaris Umum Pendeta Dr. Freddy Pattiradjawane, M.Min. ${ }^{35}$ Nahuway sendiri, sebelum menerbitkan "surat politik" PGPI itu, pernah menyatakan secara terang-terangan di berbagai forum gerejawi bahwa presiden ke depan harus yang berlatar belakang militer dan kaya. Alasannya, supaya ia tak pusing lagi memikirkan soal harta. Tidakkah jalan pikiran Nahuway itu sangat aneh? Apakah rakyat puas dengan Presiden Susilo Bambang Yudhoyono (2004-2014), yang berlatar belakang militer itu? Umumnya rakyat niscaya menjawab "tidak", karena Yudhoyono dinilai tidak tegas dan hanya mementingkan pencitraan. Apakah presiden yang kaya seperti Soeharto (1966-

${ }^{34}$ Daniel Yonathan Missa, "Ketika Tuhan Dipolitisasi", Kompasiana, 29 Juli 2014, http://politik.kompasiana.com/2014/07/29/-ketika-tuhandipolitisasi-666455.html.

${ }^{35}$ Dalam konteks Pilgub DKI Jakarta 2012, Jacob Nahuway pernah secara terbuka menyatakan bahwa dirinya dan para pendeta di PGPI mendukung Fauzi Bowo (incumbent). Tapi ternyata calon yang didukungnya atas nama lembaga gerejawi itu kalah. 
1998) tidak korup? Jawabannya: justru di akhir masa hidupnya, Soeharto dinyatakan sebagai pemimpin politik paling korup di dunia oleh PBB dan Bank Dunia, berdasarkan laporan Inisiatif untuk Mengembalikan Aset yang Dicuri (The Stolen Asset Recovery Initiative/StAR Initiative). ${ }^{36}$

Surat yang dikeluarkan PGPI, dengan merujuk Yeremia 29:7, menyebutkan: "gereja tidak boleh bersikap masa bodoh terhadap negara, gereja juga harus memberi warna terhadap negara". Tentu saja hal itu benar. Tapi pertanyaannya, mengapa gereja-gereja dalam naungan PGPI diharuskan memilih Prabowo? Ada dua alasan yang patut disoroti, karena dua alasan itu pula yang sangat layak diragukan: 1) karena ia seorang yang berintegritas; 2) karena ia memiliki komitmen dan kepedulian yang besar terhadap kepentingan gereja.

Ada beberapa pertanyaan yang layak diajukan. Pertama, apakah seseorang (Prabowo) yang sudah bercerai dengan isterinya (Titiek Soeharto), juga yang dipecat dari dinas kemiliteran negara karena tuduhan pelanggaran hak asasi manusia ${ }^{37}$, dapat dinilai berintegritas? Dengan alasan apakah Kristen dapat membenarkan kedua hal itu? Kedua, kapankah dan mana buktinya Prabowo benar-benar berkomitmen dan peduli pada kepentingan gereja?

36 Victor Silaen, "Soeharto dan Nisbinya Keadilan", Seputar Indonesia, 25 September 2007.

37 Perihal pemecatan Prabowo pada 21 Agustus 1998 dapat dibaca dari banyak sumber berita, salah satunya pemilu.tempo.co, 10 Juni 2014. 
Tak pelak, dikarenakan "surat politik" lembaga gerejawi aras nasional itu, Jacob Nahuway pun menuai kritik bahkan cemooh. Tak sedikit yang menulis surat terbuka di akun-akun facebook, juga di kompasiana (sebuah ruang yang disediakan kompas.com bagi publik yang ingin menulis apa saja). Tapi, Nahuway seakan menutup mata dan telinganya. Ia seakan pantang mundur mempromosikan Prabowo. Bahkan di Medan, dalam sebuah acara Kebaktian Kebangunan Rohani (KKR), di tengah khotbahnya, Nahuway menyempatkan diri untuk mengajak jemaat memilih Prabowo. Sontak suasana khidmat ibadah menjadi kisruh, apalagi kemudian ada seorang pemuda yang maju ke mimbar untuk mengungkapkan "protes" secara halus seraya mengatakan "Salam Dua Jari". Alhasil, untaian acara yang sudah dirancang setelah khotbah, seperti altar call, tidak jadi dilaksanakan. ${ }^{38}$

Itulah harga yang harus dibayar Nahuway akibat merusak suasana ibadah dengan mengampanyekan capres Prabowo secara vulgar. Pada saat bersamaan di Sulawesi Utara, sudah ada yang siap-siap menggalang aksi demo demi menuntut Nahuway mundur dari jabatan Ketua Umum PGPI usai hirukpikuk pilpres ini. Namun, Nahuway betul-betul tak hirau akan suara kritis dari sana-sini terhadap dirinya. Bahkan beberapa hari menjelang Pilpres 9 Juli 2014, di Jakarta Convention Centre (JCC), ia bersama-sama dengan dua pendeta lainnya (Nus Reimas dan Gilbert Lumoindong) kembali menggelar KKR yang menghadirkan Prabowo di ujung acara.

${ }^{38}$ Reformata Vol. 176, Juni 2014. 
Usai pilpres, empat hari sebelum pengumuman hasil rekapitulasi oleh Komisi Pemilihan Umum (22 Juli), yakni 18 Juli, di tempat yang sama acara kebaktian sejenis diselenggarakan kembali. Menurut Tim Kampanye Kristiani Koalisi Merah Putih (TK3MP), acara tersebut ibadah pengucapanan syukur atas kemenangan Prabowo-Hatta ${ }^{39}$. Salah seorang anggota panitia, Laksda TNI (Purn.) Christina Rantetana, mengatakan: "Kita bersyukur karena berdasarkan Pusat Tabulasi Nasional Merah Putih, kita unggul". Entahlah, meski saat itu sudah banyak tanda berdasarkan hasil penghitungan cepat hasil Pilpres 2014 bahwa pasangan JokowiKalla menang, mungkin Jacob Nahuway dan komunitasnya itu masih beriman kalau-kalau mukjizat terjadi: Prabowo menang. Tak heran jika dalam ibadah tersebut, Pendeta Edward Gultom yang memimpin doa berucap bahwa Tuhan sudah memberi kemenangan kepada Prabowo. Iman mereka mengajarkan bahwa Tuhan "sudah" memberi, bukan "akan" memberi. Tuhan "sudah" mengabulkan, bukan "akan" mengabulkan. ${ }^{40}$ Jangan heran juga jika salah seorang anggota tim sukses Prabowo, yakni Letjen TNI (Purn.) Yohanes Suryo Prabowo, yang saat itu memberi sambutan, berkata begini: Prabowo

${ }^{39}$ Muhammad Zulfikar, "Yakin Menang, Kubu Prabowo-Hatta Sudah Gelar Syukuran", Tribunnews.com, 18 Juli 2014, http://www.tribunnews.com/pemilu-2014/2014/07/18/yakin-menang-kubuprabowo-hatta-sudah-gelar-syukuran.

40 Gan Pradana, "Logika Politik dan Logika Keagamaan Prabowo", dalam kompasiana, kompas.com (31-7-2014). 
memang orangnya sangat Yesuslah." 41 Alasan Suryo Prabowo menganggap Prabowo sangat Yesus adalah: Prabowo sanggup menerima penghinaan bertubi-tubi kampanye hitam selama pilpres. Tentu saja saat itu Suryo Prabowo tidak menyebut kasus Obor Rakyat yang pemimpin redaksinya kelak resmi menjadi tersangka dan dipecat dari jabatan komisaris sebuah perusahaan milik negara, karena isi tabloid tersebut yang sarat hinaan terhadap Jokowi. ${ }^{42}$

Setelah KPU mengumumkan bahwa Prabowo kalah, pihak Prabowo pun kemudian menggugat ke Mahkamah Konstitusi (MK). Lucunya, ketika menyampaikan berkas gugatan ke MK, beberapa pendeta juga turut memberikan dukungan kepada Prabowo dengan secara demonstratif berdoa di salah satu ruang gedung MK. Sayangnya bersamaan dengan itu, ada dua paranormal yang juga melakukan ritual "keagamaan" di MK. ${ }^{43}$ Padahal cara-cara seperti ini sangat bertentangan dengan iman Kristen. Jika kelak MK memenangkan gugatan Prabowo, siapakah yang nanti akan mengklaim sebagai penyumbang kemenangan bagi Prabowo:

${ }^{41}$ Ibadah Syukur Kemenangan Prabowo-Hatta (YouTube), http://www.youtube.com/watch?v=aTj4IUO8MWg, menit 12:49.

42 Hindra Liauw, ed, "Dahlan: Setyardi Budiono Dipecat dari PTPN XIII" Kompas.com, 12 Juli 2014, http://nasional.kompas.com/read/2014/07/12/20061761/Dahlan.Setyardi.Budi ono.Dipecat.dari.PTPN.XIII.

${ }^{43}$ Liputan6.com, "Paranormal, Prabowo dan Pendeta", Laskar Pelangi Anak Bangsa, 25 Juli 2014, http://laskarpelangianakbangsa.blogspot.com/2014/07/paranormal-prabowodan-pendeta-p3.html. 
para pendeta pendoanya atau dua paranormal di atas? Syukurlah, Tuhan sudah menyatakan kehendak-Nya, bahwa yang menang adalah Jokowi - terlepas dari berapa banyak rohaniwan Kristen (juga Islam) yang berdoa buat dia.

Sikap politik PGPI jelas berbeda dari sikap politik Persekutuan Gereja-gereja di Indonesia (PGI). Sekretaris Eksekutif Bidang Diakonia PGI Jeirry Sumampow menyatakan bahwa posisi PGI sudah jelas, yakni tidak memihak salah satu pasangan capres. "Sama waktu Pileg lalu, prinsipnya PGI netral. Kita anjurkan ke warga gereja untuk menilai sendiri pasangan calon presiden sesuai track record masing-masing calon," kata Jeirry. ${ }^{44}$ Dengan begitu, ujar Jeirry, bisa menjadi pembelajaran bagi umat Kristen se-Indonesia dalam menentukan capres yang akan dipilihnya. "Jadi PGI tidak mengarahkan ke calon presiden tertentu. Kita tidak masuk ke dukung-mendukung," tuturnya. Menurut Jeirry, "PGI tidak berpolitik untuk kekuasaan. Bukan itu orientasinya. Kita memang berpolitik, tapi berpolitik secara moral."

\section{KOMENTAR BEBERAPA TEOLOG}

Dalam kaitan politik praktis Kristen atau gereja, saya secara khusus mewawancarai beberapa pendeta sekaligus teolog yang saya anggap berkompeten untuk bicara soal politik. Berikut komentar mereka melalui surat elektronik:

${ }^{44}$ http://detiknews.com, 22 Mei 2014. 
Dr. R.P. Borrong:

"Mimbar di dalam gereja atau kebaktian berfungsi untuk menyampaikan Firman Tuhan kepada umat, karena itu mimbar tidak patut (bukan soal boleh atau tidak, karena itu urusan gereja masing-masing) digunakan untuk kampanye politik, apalagi dalam mendukung satu pihak secara terbuka. Gereja adalah institusi rohani yang selalu harus menjadi tempat memberitakan Firman Tuhan, maka kebenaran Firman Tuhanlah yang harus disampaikannya dari atas mimbar gereja atau mimbar ibadah. Tentu tiap gereja mempunyai pemahamannya sendiri, tetapi pendapat saya mimbar bukan untuk ajang kampanye. Penggunaan kop surat untuk memberi dukungan pada calon presiden tertentu juga sangat ditentukan oleh keyakinan gereja yang bersangkutan akan fungsi surat dan otoritas pejabat gerejanya. Kalau gereja tersebut meyakini bahwa pemimpinnya punya otoritas menggunakan surat untuk menghimbau jemaatnya mendukung calon tertentu, hal itu sah saja kalau memang didukung oleh peraturan dan tata laksana gereja bersangkutan. Tetapi sekali lagi, gereja sebagai institusi tidak patut menggunakan fasilitas apapun dalam gereja untuk menjadi ajang kampanye atau dukung-mendukung calon dalam event politik praktis. Domain gereja adalah memberitakan Firman Tuhan dan menghimbau jemaatnya untuk melakukan kewajibannya sebagai warga negara menurut keyakinan dan kata hatinya sendiri."

Dr. Eddy Paimoen:

“Dalam pembangunan bangsa, gereja memiliki jemaat yang 
menganut politik yang berbeda-beda. Sangat tidak etis kalau seorang pendeta mengarahkan jemaatnya untuk memilih partai tertentu dan memilih orang tertentu dengan menyebut sebuah nama. Pendeta seharusnya berbicara tentang teologi dan etika politik, dan bagaimana peran politik jemaat." 45

Dr. Zakaria Ngelow:

"Dalam pemahaman saya, seorang pendeta berkewajiban membina warganya untuk berpartisipasi dalam politik dengan baik, yakni menggunakan hak pilihnya secara 'luber' sesuai pilihan pribadi masing-masing. Tugas pendeta dalam hal ini bukan menyodorkan nama capres tertentu, melainkan melakukan pendidikan politik kepada warganya supaya masing-masing dapat memilih sebagai warga yang melek politik. Yang bisa dilakukan antara lain, mengembangkan bersama kriteria capres yang ideal, atau memfasilitasi warga dengan pengenalan mendalam semua calon. Dengan menyodorkan nama capres tertentu maka tidak berlangsung pendidikan, melainkan pembodohan politik. Lagi pula dengan mengkampanyekan seorang capres dari mimbar gereja, maka sang pendeta mengubah statusnya dari pelayan firman Tuhan menjadi juru kampanye atau tim sukses capres tertentu. Pada prinsipnya pendeta juga harus menghargai kedewasaan warganya memilih dan menghargai pilihan yang berbeda di kalangan warganya. Karena itu tidak boleh mendukung salah satunya. Nasihat pastoral pendeta bagi warga terkait dengan

${ }^{45}$ https://www.facebook.com/epaimoen?fref=ufi. 
pendidikan politik di atas. Tentang penerbitan surat dengan kop resmi, ini sifatnya institusional karena terkait dengan aturan main dalam gerejanya. Dalam sistem presbiterial sinodal (misalnya GPIB) atau episkopal (misalnya HKBP) surat seperti ini seharusnya berisi keputusan badan pimpinan sinodal gereja yang bersangkutan, dan ditandatangani bersama sekretaris sinodenya. Dalam gereja-gereja pentakosta/kharismatik ada yang mengembangkan sistem kepemimpinan tertinggi yang mengakui kewenangan penuh sang pemimpin mengambil keputusan, apalagi kalau sudah disertai legitimasi wahyu misalnya atas perintah Roh Tuhan. Terlepas dari sistem pemerintahan gereja itu, seharusnya gereja sebagai lembaga tidak diseret ke dalam 'politik praktis', supaya gereja tidak membebek pada penguasa, dan tidak kehilangan wibawa suara kenabiannya ketika harus menyatakan kehendak Allah terhadap kezaliman penguasa."

\section{Dr. Richard Daulay:}

"Bagaimana kalau lembaga gerejawi menerbitkan surat resmi untuk mendukung salah satu capres tertentu? Dari kacamata etika politik jawabannya ya dan tidak. Ya, kalau bangsa sedang dalam situasi krisis seperti era aphartheid di Afrika Selatan. Desmond Tutu berkata: 'In the time of injustice to be neutral is to take side pro satus quo'. Tidak, kalau dalam situasi normal seperti Indonesia sekarang. Menurut saya sikap teman-teman pendeta yang membawa organisasi gereja memihak kepada capres tertentu adalah berlebihan. Ada buku bagus tentang ini: Christian Perspective on Politics, oleh J. Philip Wogaman." 
Dr A.A. Yewangoe:

"Sebagai institusi, gereja hanya menyampaikan kriteria, bukan nama. Pilihan pribadi pendeta tidak harus menjadi pilihan jemaat. Kita harus yakin bahwa jemaat sudah cukup dewasa untuk menentukan pilihannya sesuai nurani. Tidak usah harus didikte."

\section{REFLEKSI}

Sebuah pertanyaan reflektif menjadi penutup tulisan ini: mengapa Ketua PGPI Jacob Nahuway bisa melakukan hal yang vulgar dalam konteks politik praktis, Pilpres 2014? Tidakkah dia mengerti bahwa sebagai pemimpin gereja, apalagi pemimpin lembaga gerejawi aras nasional, secara etika dia tak pantas melakukan hal itu? Jawabannya sederhana: itulah sebentuk kenaifan berpolitik, selain tentu saja "ada udang di balik batu".

Pilpres 2014 ini memang sangat fenomenal bagi Kristen, karena Tuhan telah membukakan mata hati kita untuk melihat bahwa para hamba Tuhan pun bisa jatuh ke dalam akar segala kejahatan: cinta uang. "Sebab oleh memburu uanglah beberapa orang telah menyimpang dari iman" (1 Tim. 6: 10). Benar, itulah sebentuk tindakan melacurkan diri secara rohani.

Tak usah heran, permainan kekuasaan dan uang di atas mimbar sakral memang sudah ada sejak zaman Yesus. Injil Lukas (14:47) mencatat, di zaman itu Bait Allah di Yerusalem dikuasai oleh imam besar, ahli Taurat dan para petinggi agama. Padahal imam besar dan petinggi agama waktu itu menerima kekuasaan mereka dari Pilatus, penguasa 
Romawi yang berkuasa atas Yudea (Luk. 23:1-5). Bait Allah juga ternyata menjadi tempat kotor permainan uang korupsi hewan korban dan ibadah ziarah. Tak heran jika Lukas juga mencatat: Yesus marah dan mengusir semua pedagang dari Bait Allah. "Kamu telah mengubah Rumah Doa menjadi sarang penyamun!" kata Yesus (Luk. 19:46). Injil Yohanes bahkan mencatat dengan lebih tegas: "Ketika hari raya Paskah orang Yahudi sudah dekat, Yesus berangkat ke Yerusalem. Dalam Bait Suci didapatinya pedagang-pedagang lembu, kambing domba dan merpati dan penukar-penukar uang duduk di situ. Ia membuat cambuk dari tali lalu mengusir mereka semua dari Bait Suci dengan semua kambing domba dan lembu mereka; uang penukar-penukar dihamburkan-Nya ke tanah dan mejameja mereka dibalikkan-Nya" (Yoh. 2:13-15). 